\title{
Philosophy of ceiling Design in French Style interiors
}

\author{
Enas Anoos \\ Assistant Professor, Departement of Interior design, College of Art and design, King Abdulaziz University, \\ Kingdom of Saudi Arabia, Jeddah.
}

\begin{abstract}
The treatment of the ceiling has seen the mid-sixteenth century new developments inspired by the great Italian and examples that changed the architectural balance of the piece by more closely integrating the decoration of the walls that they covered, and thus accentuating unity of the confined space. The series culminates with the evolution of a program ceiling of Versailles, but works undertaken in large Parisian houses from the 1630 has helped to define the new section of the ceiling, offering artists a vast field of activity. Research will continue in mid-century, in order to completely conceal the supporting structure and integrate the ceiling to the architecture of the space.
\end{abstract}

Keywords: Ceiling design, French Architecture, Style Louis XIII and Louis XIV.

\section{INTRODUCTION}

The interior design plays a vital role in artistic creation in France in the seventeenth century. Decorative sets made in the french private hotels or palaces during the first half of the seventeenth century are considered a major activity of expression painters.In the middle of the sixteenth century, The treatment of the ceiling has seen new developments inspired by the great Italian examples. There is a chronological succession as aesthetic that would lead from the ceiling with beams and joists to the ceiling with vaults, it is the gradual replacement of a traditional part of France by an imitation of the Italian mode with an intermediate step, the partition.

\section{Ceiling with painted beams and joists.}

\section{ANALYSES}

Paris harbours many examples of early seventeenth century ceiling with painted beams and joists. Less prestigious than the ceiling in the Italian style, who can develop stories in a stucco framework, ceiling with painted beams and joists, is also called à la française or ceiling in the french style [1].The ceiling with painted beams and joists preserved in Paris, dating back to the years 1580-1650, period during which they present a homogeneity of form and style [2].This simple and natural process does not belong exclusively to the first half of the seventeenth century but it is widespread in the Middle Ages, not only in principle, but also in terms of form.During the Renaissance, not only the ceiling with painted beams and joists resist, but its decorative system is renewed. In large royal houses, where the Italianism penetrates more readily, the French ceiling is always represented. In Fontainebleau palace, the Guard Room and the galerie des cerfs are covered in this way, like the Caryatids room in the Louvre, vaulted in 1630 only. The early 1660 s can be considered as the period during which disappears the ceilings à la française [3].

\section{Structure of ceiling with beams and joists.}

-Before playing a decorative role, the ceiling with beams and joists belongs to the internal structure of the building, implemented during the construction of the shell of the building by the master carpenter and its painted decoration covers without changing the assembly of structural members that make up each level. [4]

- Two construction elements are used in since the Middle Ages: the beam and the joist. The ceiling consists of several rows of equally spaced joists together and separated by beams launched between the walls. This tipe, which was then one of the solutions offered by the art of the carpenter finally prevail to become the single model in the seventeenth century.

-Launched a wall to another, the beam enters the masonry walls and can sometimes be supported by stone corbels. [1]

- the joist is a piece of smaller and smaller-scale section, placed between the beams. It can be placed on the beams and not engraved in it, but it relies mostly on a lambourde, a piece of wood attached to the side of the beam.

- Stability rules governing the implementation of these two elements of carpentry: beams, a maximum range of 8 to 10 meters, are usually spaced with each other about 2 to 3 meters, forming a bay (in Paris, a span joists are 21 on average). 
- The joists are separated by a space, called casebays, which consists of a wooden board attached to the top of the joists. The width of the casebay is variable: if Palladio recommends a half times the width of a joist, Le Muet and Savot advocate under Louis XIII spacing equal to the width of a joist, According to the rhythm" "As full as empty."

The structure thus obeys to a precise and decorative binding, which aims to give an impression of cohesion despite the fragmentary and repetitive spaces decorated beams, joists, and interjoists frieze.

-The structure thus obeys to a particular and binding ornamental system, which aims to give an impression of cohesion despite the fragmentary and repetitive spaces decorated: beams, joists, casebays (interjoists) and frieze.

\section{Characteristics of ceiling with beams and joists}

-This ceiling has indeed two advantages: also that its implementation is cheap, as part of the building structure, it does not require, with its form , the services of a painter controlling large format and perspective. -Incompatible with the great decor allegorical or mythological, the ceiling with beams and joists, can only receive an anecdotal speech, composed of decorative motifs arranged in a regular pattern and necessarily repetitive : if it is sometimes decorated with cartridges or small scenes - landscapes, battles, gods ... - their dimensions, subject to those beams, correspond to the small easel paintings.. (Gruber, Pons, Reinhardt and Molen),

-The ceiling with beams and joists is highly symmetrical: they give an impression of strength, very significant when looking at the beams and joists in left natural.

-A relationship seems to be established between this type of ceiling and rooms that adorns: beams and joists are admirably suited to antechambers, the guard room, and the long galleries - Oiron, Ancy-le-Franc , Ecouen, Fontainebleau, Luxembourg - Rooms noble (chambers, cabinets ...) are decorated with more wealthy ceilings requiring the intervention of artists [4]

-The ceiling with beams and joists are receding, but are replaced only gradually: a small room on the ground floor at the Hotel Lambert Louis Le Vau, dating from the first season of decoration of the hotel, before 1644, is covered with a French ceiling: à la française . [5]

Near Paris, the Vaux-le-Vicomte palace, built in 1657-1660, also includes in the old large square room on the ground floor a large ceiling with painted beams and joists with with a frieze of Le Brun himself [6].

\section{Surface treatment}

The performer painted the decorations on the beams and joists once the ceiling mounted, by means of a scaffold. The pieces of wood, beams, joists, lambourdes and casebays, formed the natural support of the decor. [1].

Painting completes the decoration of the French ceiling but must emphasize the "depth" of the ceiling depth that comes from three successive shots and more and more distant from the eye, formed by the beams, joists and casebays.

The painting covers four supports, beams and joists, their three faces visible, casebays or interjoists and finally the top of the walls, the latter portion of frieze. This element plays a role transition identical to that of the ledge: usually from a height of from 30 to $40 \mathrm{~cm}$, it ensured visually the integration of large beams in the overall composition appearing to continue their painted decoration on the top of the wall.

\section{The decorative system}

The decorative system of the ceilings à la française is based on a large unit set, obtained by the repetition of motifs painted and color harmony.

\section{Principles of the decorative system}

Three principles, intended to avoid too great monotony, govern the set of beams and joists:

\section{The hierarchy of elements together}

The designer plays first on the hierarchy between the painted surfaces; thus, casebays and the sides of the joists are usually more soberly decorated than the main face of the joists: nets drawing geometric panels , simplicity of rare rosettes ... The joists themselves are less ornate than the large beams. Thus is formed a gradation that simultaneously respects the hierarchy of pieces of wood construction and gives the viewer's eye moving around the room a variety not of motifs but impressions.

\section{-Division of the constituent parts:}

The decorator then divided beams and joists, parts by their nature long and thin, in several successive and autonomous spaces. Organized around a central motif or two motifs on the sides , these kinds of "panels" 
are linked on a single joist or beam by the same nets, usually colored or gray: grisaille that frame, crossing and uncrossing.

\section{- The alternation of decorative motifs used :}

The painter was always careful to alternate between them the decorations of the joists, which are typically two types in a room ; some with central motif and the other with sides motifs "Fig. 4" . This is reinforced by the alternating colored backgrounds, sometimes light and dark, brown and white, or two contrasting colors, for example green and red or blue, red and ocher lined with fine white stripes.

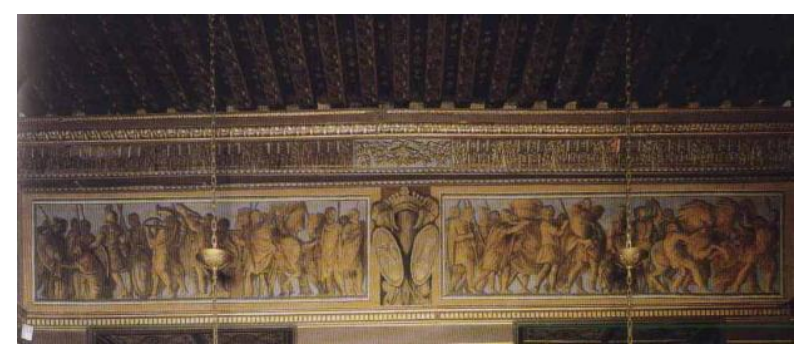

\section{Ornaments:}

\section{Figure4: Detail of the ceiling of the hall at the hotel Sully (1630-1640)}

On the friezes and beams: that offer the painter of larger surfaces, focus the motifs most wanted, with horizontal format and placed in cartridges or leather with rich windings. These parts can be :

-Fine-pieces: the Italian landscape with a sense of depth "Fig. 6", battle scenes with horsemen, deities ancient children playing or blowing trumpets, the owner figures with or without heraldic motif... Motifs that are also found in the painted paneling that grow under Louis XIII.

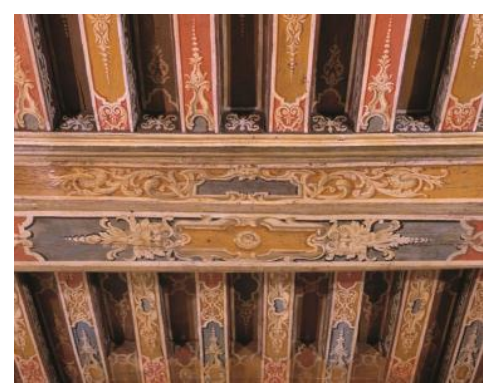

Figure 6: Italian Landscape in a cartouche adorn one of the beams on the ceiling of the Berlize hotel in the early 17 th century

-The anthropomorphic representation: it is often of average quality: female masks accosted foliage, grotesque heads "Fig. 7", small words and children and Symbols of love.

-Wildlife: is rarely used like the dogs' heads or griffins adorning the beam on the ceiling of some hotels in Paris.

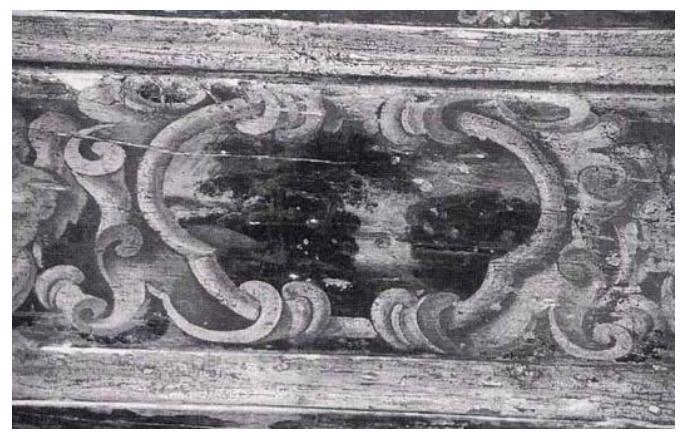

Figure7: grotesque head in a medallion, detail of a beam in the ceiling of the Lebys de La Chapelle.1644

- The decorative motifs of repetitive type: which cover the joists and most parts of the beams . They are very different and are great freedom of execution.

-The classic motifs from ancient architecture are rare: the friezes of posts, friezes oves (often on the lambourdes), the greek and denticles, however, are absent from the ceilings kept in Paris.

- Flora provides an inexhaustible repertoire, which is not unique to the beams and joists: all ceilings offer rosettes and stylized motifs (scrolls, wreaths, garlands of leaves or arranged in vases or rolls frieze, the olive 
leaves on a winding stem. Baskets of flowers or bouquets"Fig. 8" may even be the central motif of a cartridge on a beam, as in hotels Passart and Berlize [7].

On the lambourdes also painted, there is usually a frieze of leaves, sometimes decorated with flowers or shells.

On the casebays which are generally less decorated, there are: net geometric friezes of circles or diamonds, some less colorful flowers or represented more simply.

The sides of the joists are well suited to simple friezes of flowers or repetitive motifs.

\section{The colors}

Many motifs are painted in grisaille, "black and white." The colors used for the funding of the beams and joists, determine the general tone of the ceiling. These ceilings can be divided into two general types:

Ceiling in quiet tone: played on a single color, usually brown, more nuanced in highlights and shadows, in the spirit of shades camaieu. On the ceiling of the Hotel de Launay, the effect is almost that of a marquetery in the style of carpentry ceilings of the Renaissance: stoats, olive flowers, wreaths and trees painted in beige and gold are set against a brown background [1].

Ceiling in vivid tone : Plays on the contrast of colors funds joists, for example white and brown, gold and black, but especially on the contrast between bright colors: blues (rare), red, green .. . which give the ceiling a brightness enhanced by gold nets and borders (frames, leather).

\section{Partitioned ceilings}

In between 1630 and 1650 , a decorative formula achieved great success, the partitioned ceiling.It would be tempting to explain its success as a normal evolution of the fine arts which combined the traditional solution of painting on joists, adopted first in Italy and then in France, with the emergence of coves which offer greater possibilities for the artist[2].

\section{Structure of Partitioned ceilings}

On the underside of the of beams and joists, attempts were made early to draw another geometric arrangement allowing to escape the repetition of narrow parallel by determining a repetitive grid of small boxes or larger compartments for receiving a carved or painted decoration. In Italy as in France, these ceilings carpentry saw early a great favor in the mansions [8].

\section{Ceiling of the apartment of Madame de La Meilleraye in the Arsenal}

Reinforces the idea that designers install more readily in 1630 - 1640 paintings inside the frame formed by the main beams of a room and tend to disappear a little bit of structure. The decorator has used the cross beams which compartmentalize the ceiling in several areas,outer belt where he places a series of allegories and attributes whose iconography is related to Charles de La Porte, and in the central box a scene of Apollo and the muses. The composition here is set up as a flat painting.. [4]

\section{Nicolas Dushesne and the partitioned ceilings}

We attribute to the painter Nicolas Dushesne a project that relates to the apartment of Queen Marie de Medicis in the Luxembourg Palace. The project appears as a "floor" completely covering the surface of the ceiling, decorated with ornamental motifs, with a number of vacant space so that we can deposit paintings inside, probably glued paintings marouflage[9] "Fig. 11".

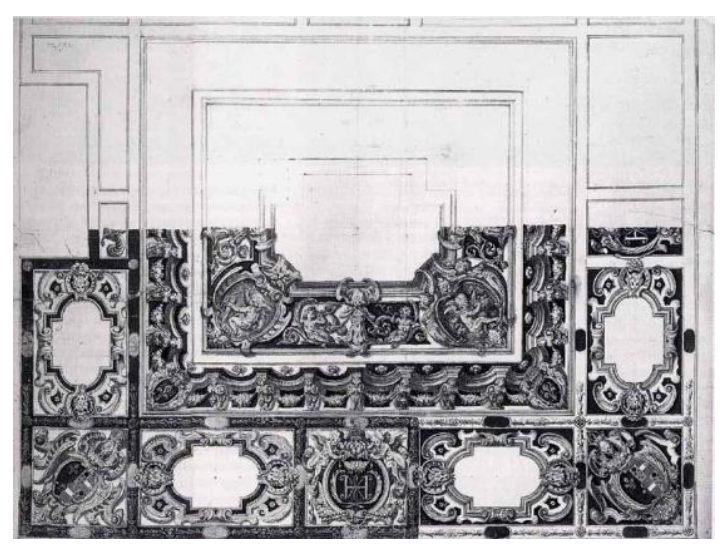

Figure 11: Project for the ceiling of the cabinet of Marie de Medicis in the Luxembourg Toussaint Dubreuil and the partitioned ceilings 
On a drawing by Toussaint Dubreuil (1561 -1602) in the Louvre, we find that the surface is structured by a set of moldings reminiscent of the cross beams, inside which appear in the medallions decorated with reliefs scenes stories. The arms of the king show that the project is to one of the residences of Henry IV [9].

\section{The partitioned ceilings ceiling and some difficulties}

The difficulties encountered by the illustrator: In a room of ancient structure and unusual shape, the painter is forced to place his compositions with no real order on a surface, interrupted by the alignment of the beams. The decorative effect is almost inexistent, the link between painting and architecture is clumsy. The unequal size of the sites left to the painters' brushes (one large compartment surrounded by four smaller, as the Arsenal) foreshadowed the subsequent disposition [8].

\section{The role of Simon Vouet, a form of innovation}

Simon Vouet played a capital role in the development of the painted ceiling in Paris in the seventeenth century. By combining some trends and elements used in the sixteenth century with his knowledge of Italian ceiling, in particular the one painted by Annibal Carrache and his workshop in the Farnese gallery in Rome , Vouet would reinvent the genre. Sets due to Simon Vouet and members of his workshop has been translated in a new direction, that of a subdivision rather than playing on the ceiling surface but taking advantage of its thickness and placed inside imaginary views that can not be confused with quadri riportati according to the formula we have mentioned above.

\section{Ceiling of chateau Neuf de Saint- Germain- en-Laye}

By 1637, for the ceiling of the chamber of the queen, Simon Vouet includes a series of four compositions "aerial" installed in the thickness of as many partitions. The paintings represent the allegories of Justice, Temperance, Force and Prudence [10].

\section{The ceiling of Mazarin palace}

On the ground floor of the left wing (now department of maps and plans at the National Library of France): we attribute to Vouet this irregular octagon ceiling with a central female figure - a Victory according Dezallier - surrounded by allegorical representations evoking Mazarin.

During his life, Vouet bring into play all the possibilities of foreshortening, trompe-l'oeil, colour and light in his painting of ceilings represented as open spaces in the sky. He would exert a powerful influence over all the artists who came into contact with him or trained in his studio, such as Eustache Le Sueur and Charles Le Brun. His pictorial language would be taken up by his main collaborator, Michel Dorigny who with the ceiling of Mazarin room(1650-1655) provides an example of consummate elegance in its variety and profusion. Same wing on the 1st floor, the ceiling of Dorigny has two partitions or compartments one on either side of a beam, in one the fortune and The abundance in the other ; monochrome medallions camaieu in the corners set of trophies and allegories.

\section{The system of coving}

Since the Renaissance, the cove or vault where the ceiling joins the wall has been one of the focal points of state room decoration. Between 1640-1660, a number of artists in Paris would take full advandage of the examples of the Italian Renaissance and early baroque to break with partitioned ceiling and the ceiling with cove imposed itself in the parisian residence during the decade 1650-1660. The return of several major artists to Paris- Vouet, Perrier and Le Brun - should accelerate the adoption of the system of coving. For Vouet, Perrier, Le Sueur and above all Le Brun, the cove should frame the principal subject and make its meaning intelligible. The cove brings into play all the artistry of trompe-l'oeil sculpture and architecture as well as stucco reliefs.It offsets the illusion of space in the ceiling with an impression of enclosure .By associating the image with all manner of ornamentation, it developed a complex iconographie. It presented a system, a hierarchical language which plays on several levels of meaning, and so doing combines all the difficulties of composition.

\section{Structure of ceiling with cove}

Unlike the ceiling beams and joists, The development of arches covered with lath and plaster allowed painters to offer larger areas than before and in one piece. This process was notably used by the architect Le Vau in his rooms in the italian style, taken on two levels, and covered with an arch, very different from the ceiling with beams and joists [2]. 


\section{Definition of the cove}

The cove is the concave surface buying the top of the walls with the ceiling. Of varying sizes, but often important in small rooms, compared to the size of the central partition. The cove is distinct from the simple frieze which accompanied the ceiling with beams and joists or partitions. It becomes an essential element of the set, it often overshadowed by his magnificence the ceiling itself .

Extension of the wall, it is somehow the earth as opposed to ceiling that evoke the sky. Hence its solid appearance, strong structure. olives or caissons, even if it is somehow the heir. It becomes an essential element of the set, it often overshadowed by his magnificence the ceiling itself, Hence its solid appearance, strong structure[8].

In a ceiling, the parts expected to open to the sky are different from the cove but complementary. Occupying the top of the walls, the decor of this must extend them, so give the eye a sense of stability and contrast with the intangible nature of the set ceiling.Italian decorators of the Renaissance had suggested several ways: imitation in painting of solid and opaque materials, monumental figures sitting on the cornice, statues, that appear to rest on it as on a shelf , architecture foundation who soar to the sky. Thanks to quadratura, artists manage to unite in a logical manner satisfactory to both the eye and for the reason, the walls closed and the open ceiling.

\section{The ceiling of the Barberini palace and the Italian tradition}

The Glory of the reign of Urban VIII, conducted between 1633 and 1639, offered perhaps the best example of open cove. Frame is given by four uprights supporting a framework, Painted in grisaille and trompel'oeil sculptures, garlands and medallions, she reveals scenes land on all four sides and the center, a heavenly apotheosis. The architectural lines of force are again clearly visible. The angles of the arch, in particular, are underlined by the figures of gray-backed and octagons with feigned relief of gilt bronze. [11].

\section{The ceiling of the room with alcove in Colombes palace}

This ceiling gives the best idea of the art of Vouet. It was directed by his pupil Michel Dorigny, the central partition represented the Union of Love with Bacchus and Venus. Each side of the cove, punctuated by consoles, has in the center an imaginary bas-reliefs of gilt bronze evoking one of the four Elements; In the angles, pairs of figures reveal, by removing curtains, scenes related to the seasons. The robust forms and movement are amplified by the agitation of draperies. The robust forms are amplified by the agitation of draperies. The figures are essential for framing and ornamentation in this set. [10].

\section{The decorated cove in royal palaces}

We must recall here the important role played by Giovanni Francesco Romanelli, the most prestigious student of Pierre da Cortonne. During his second stay in Paris, between 1655 and 1657, he decorated the apartment of Anne d'autriche at the Louvre. In the salle des saisons, the cove is more important than the ceiling.It alternates riportati large quadri riportati, featuring Apollo and Diana (which appear in the center), and elements in white and gold stucco made by Michel Anguier and his workshop: Atlantis or satyrs frame medallions evoke other Olympians [4].

\section{Ceilings with cove at Versailles}

At Versailles appeared the boldest solutions. In the salons planets that form the large apartment of King (1673-1680), several solutions were tried, from the most closed to the most airy. We emphasized the consistency of the iconographic program. These ceilings, inspired by Roman models are as many answers to so strictly geometric design advocated by Abraham Bosse.

\section{The ceiling of the Salon of Venus}

The decade 1650-1660 was marked by the achievements of Charles Le Brun. Taking over from the height of Perrier and his memories of Italy .He assured the triumph of the ceiling with cove as seen in the Salon of Venus . In the ceiling, colored quadri riportati seem set on the cornice in front of other paintings in grisaille. Overlap which remember the game on the frames of the Farnese Gallery "Fig. 19". Unlike many of his colleagues, as Le Sueur or La Hyre, seduced by the rules of real perspective, Le Brun did not care a shortcut right, unpleasant to the eye, and a point single view, intellectually satisfying, but binding[12]. 


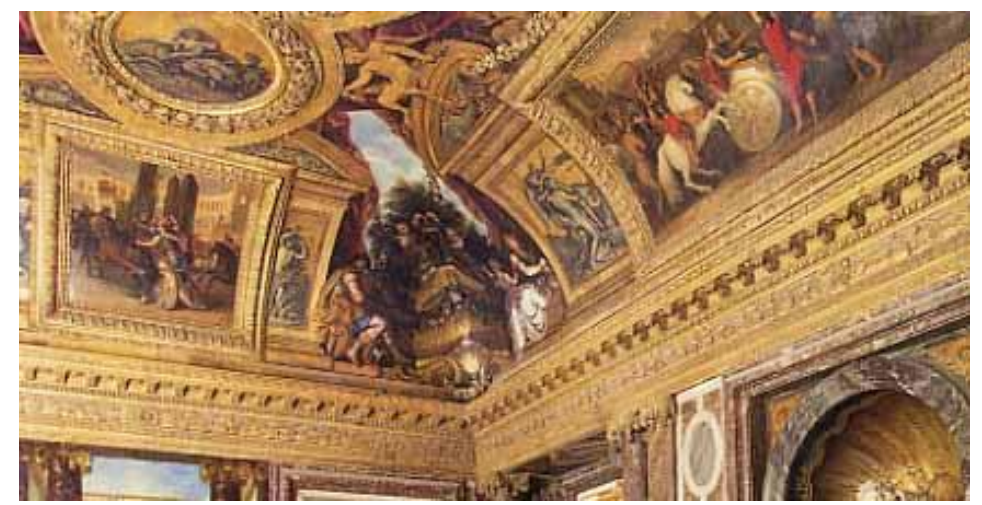

Figure 19: Ceiling of the Salon de Venus .Versailles. (1673-1680)

Finally, in the Salon of Abondance (1683), Rene Antoine Houasse unifies ceiling and cove (Figure20): skies with a few figures in flight occupies all the space and is bordered by a balustrade sham supporting vases and beautiful carpets, while the figures are looking toward the visitor [13].

\section{CONCLUSION}

The progress of the french ceiling during the 17th century, towards unity and openness illusionist were continuous and irresistible. During the years 1699-1700, a new style is emerging, one of whose characters would be the insensible passage walls to ceiling, passage whose main effect of dissolving the relation between wall and ceiling and therefore to cancel the architectonic role of the cove. References to ancient times are frequently, an ancient modeled on Roman models. Often used the white stucco and gilded, false reliefs painted in imitation of marble or bronze medallions or monochrome gray or blue. We must summon all the arts (that the only painting that is able to imitate) for the glorification of the master of the house, offer different levels of meaning and different reading. The control and visual -culture of the best artists and decorators in Paris had become such that they could carry in turn the storied cove or mainly ornamental. It illustrates, in appropriate subjects, a dominant theme. The royal decorations, especially at Versaille are exemplary in this regard: the ceiling coves are making a political speech more or less direct, involving associating a particular divinity of the Fable to virtuous example from history.

\section{REFERENCES}

Gady, A., Poutres et solives peintes. Le plafond «à la française». Revue de l'Art, 122(4), 1998, pp.9-20. Babelon, J. P., Demeures parisiennes sous Henri IV et Louis XIII. Paris: Hazan. 1991.

Boudon, F. Blecon, J.and Grodecki, C.,. Le château de Fontainebleau de François Ier à Henri IV. Paris: Picard. 1998 Barielle, J. F., Les styles français. Paris: Flammarion, 1998.

Beatrice, A.and Courtin, N. , L'Île Saint-Louis. Paris: Action Artistique de la Ville de Paris. 1997.

Pérouse de Montclos, J. M., Vaux Le Vicomte . Paris: Scala . 2002

Mérot, A ., Retraites Mondaines aspects de la décoration intérieure à Paris, au XVIIe siècle. Paris: Gallimard . 1990.

Feray, J ., Architecture intérieure et décoration en France des origines à 1875. Paris: Berger-Levrault. 1997.

Thornton, P ., L'epoque et son style. La décoration intérieure 1620-1920. Paris: Flammarion. 1997.

Thuillier, J., Vouet. Paris: Réunion des Musées Nationaux. 1990.

Blunt, A., 1983. Art et Architecture en France(1500-1700). Paris: Macula. 1983.

Milovanovic, N., L'iconographie des grands decors monarchiques(1653-1683)de la fin de la fronde à la mort de Colbert. Paris: Les Belles Lettres. 2002.

[13] Sabatier,G ., Versailles ou la figure du roi. Paris: Albin Michel . 1999. 